\title{
Modeling effects of GABAA receptors in basal ganglia computational models
}

\author{
Félix Njap ${ }^{1,2^{*}}$, Andréas Moser ${ }^{3}$, Ulrich Hofmann ${ }^{1}$ \\ From Twentieth Annual Computational Neuroscience Meeting: CNS*2011 \\ Stockholm, Sweden. 23-28 July 2011
}

$\gamma$-Aminobutyric acid (GABA) is a major inhibitory neurotransmitter in neurons of the basal ganglia. Recent experimental studies demonstrate that high frequency stimulation (HFS) does not only need presynaptic GABAA receptors but also intact GABAergic nerve terminals coupled to GABAA receptors to exert an inhibitory effect [1-3]. This effect may result to the modification of basal ganglia activity, exactly how has still not been clearly determined. Using a computational approach, our current contribution analyze the firing patterns of different synaptic conductances input applied to the subthalamic nucleus (STN) neuron in Parkinson's disease (PD) state and compare this to the normal state. Our contribution is based on Rubin and Terman's PD computational proposed model [4]. To carefully examine the similarity or dissimilarity between both firing patterns, we used four-based spike metric similarity measures, Victor Purpura spike train metric, Van Rossum, Schreiber et al. and Hunter-Milton similarity measures $[5,6]$. In this work, we were able to investigate the direct effect of GABAA receptor on STN spiking activity, and our analysis provides also simple guidelines useful to search parameters that maximize irregularity.
References

1. Moser A, Gieselberg A, Ro B, Keller C, Qadri F: Deep brain stimulation: response to neuronal high frequency stimulation is mediated through GABAA receptor activation in rats. Neurosci. Letters 2003, 341:57-60.

2. Mantovani M, Moser A, Haas CA, Zentner J, Feuerstein TJ: GABAA autoreceptors enhance GABA release from human neocortex: towards a mechanismfor high-frequency stimulation (HFS)in brain? NaunynSchmiedberg's Arch Pharmacol 2009, 380:45-58

3. Hiller A, Loeffler S, Haupt C, Litza M, Hofmann U, Moser A: Electrical high frequency stimulation of the caudate nucleus induces local GABA outflow in freely moving rats. J. Neurosci. Meth 2007, 159:286-290.

4. Rubin RJE, Terman D: High Frequency Stimulation of the subthalamic Nucleus Eliminates Pathological Thalamic Rhythmicity in a Computational Model. J Comput. Neurosci 2004, 16:211-223.

5. Dauwels J, Vialatte F, Weber T, Cichocki A: On similarity measures for spike trains. Advanced in Neuro-Information Processing 5506:177-185.

6. Victor JD, Purpura KP: Metric-space analysis of spike trains: theory, algorithms, and applications. Network 1997, 8:127-164.

doi:10.1186/1471-2202-12-S1-P106

Cite this article as: Njap et al:: Modeling effects of GABAA receptors in basal ganglia computational models. BMC Neuroscience 2011 12(Suppl 1): P106.

\section{Acknowledgments}

This work was supported by the "Graduate School for Computing in Medicine and Life Sciences" funded by Germany Excellence Initiative [DFGGSC235/1].

\section{Author details \\ 'Institute for Signal Processing, University of Lübeck, Lübeck, D-23538, Germany. ${ }^{2}$ Graduate School for Computing medicine and Life Sciences, University of Lübeck, D-23538, Germany. ${ }^{3}$ Department of Neurology, University of Lübeck, Lübeck, D-23538, Germany.}

Published: 18 July 2011
Submit your next manuscript to BioMed Central and take full advantage of:

- Convenient online submission

- Thorough peer review

- No space constraints or color figure charges

- Immediate publication on acceptance

- Inclusion in PubMed, CAS, Scopus and Google Scholar

- Research which is freely available for redistribution
C Biomed Central 